ADAM, K. M. G. (1953). J. gen. Microbiol. 9, 876-884.

\title{
In vivo Observations on the Giliate Protozoa inhabiting the Large Intestine of the Horse
}

\author{
BY KATHERINE M. G. ADAM \\ Department of Biology, Royal (Dick) Veterinary College, Edinburgh*
}

SUMMARY: The ciliate population of the large intestine of the horse shows large, daily variations. The ventral colon is the site where the ciliate fauna varies most. Two species, Cycloposthium edentatum and $C$. dentiferum, became established in the large intestine after passage through the stomach and small intestine. The introduction of new species into the ventral colon caused significant changes in the fauna of that part of the gut.

In a previous paper (Adam, 1951) the author reported the number and species distribution of ciliates in samples obtained from the large intestine of slaughtered horses. Since then, Alexander (1952) has devised a method of making fistulae into the large intestine of the horse, and it has therefore been possible to investigate the ciliate protozoa in vivo. The object of the present work was threefold: $(a)$ to follow the day-to-day variations of the ciliate population when feeding a standard diet to the horse; $(b)$ to study the effect of changes in the diet; (c) to obtain information on how the horse may acquire its ciliate fauna.

\section{METHODS}

Observations were made on two ponies designated $A$ and $B$. Pony $A$ had fistulae into the caecum and ventral colon and pony $B$ had fistulae into the caecum, ventral and dorsal colon. Approximately $100 \mathrm{ml}$. of gut contents were taken daily from each fistula for total and differential counts of ciliates.

The counting method previously described (Adam, 1951) was slightly modified. Since the gut contents taken from the fistula were always fluid, it was more convenient to take a measured volume instead of a particular weight of the digesta. The sample, which contained suspended material, was immediately transferred to a measuring cylinder, made up to twice its volume with $5 \%(w / v)$ formalin, and allowed to stand for $15 \mathrm{~min}$. After tilting the cylinder six times to mix the suspension, $100 \mathrm{ml}$. was decanted into a large flask and the volume made up to 1,2 or more litres with tap water, depending on the dilution required to give a suitable concentration for counting. To $2 \mathrm{ml}$. of this suspension were added 2 drops of acid methyl green and $2 \mathrm{ml}$. of glycerol, and counts of ciliates were done in a Sedgwick-Rafter cell of $1 \mathrm{ml}$. capacity. This simplified method of estimating the total number of ciliates in a sample of gut contents is both rapid and accurate. Duplicate counts made on the digesta at the various stages of dilution did not differ significantly.

* Now at the Department of Zoology, Edinburgh University. 
Differential counts were made on samples that were fixed in formalin but not diluted further. Five $\mathrm{ml}$. of the concentrated suspension were placed in a test tube and a few drops of acid methyl green were added to it. The suspension was well shaken before removing a drop for examination under the $4 \mathrm{~mm}$. objective of the microscope. The first 200 (approximately) ciliates seen were separated into species and the proportions expressed as a percentage of the total count. The accuracy of this method was tested by performing counts of 200 and 1000 ciliates in a sample which contained twelve species. Ten consecutive counts were made for each group and the mean percentage value for each species was calculated. Since the differences between the means fell within the random sampling error of the counts, it was concluded that counts of more than 200 ciliates were unnecessary.

The first series of experiments was carried out on pony $A$ which was given four different diets in the following order: (1) grass only; (2) grass plus $2 \mathrm{lb}$. oats daily; (3) hay only; (4) hay plus $2 \mathrm{lb}$. oats daily. It was maintained on each diet for 3 weeks, and twenty daily records of the ciliate population were obtained for each of the four diets. The second series of experiments was carried out on pony $B$, which was fed with grass only for a period of 4 weeks and then with hay only for 4 weeks; again twenty records of the ciliate population were made for each diet.

The $\mathrm{pH}$ value of the gut fluid was measured with a glass electrode connected to a Marconi pH meter.

Since the composition of the ciliate population differed in the two ponies, attempts were made in various ways to introduce species from one animal into another. About $100 \mathrm{ml}$. of strained contents from the ventral colon of $A$ were given to pony $B$ by stomach tube. A small quantity of faecal material from pony $A$ was moistened with water, mixed with oats and fed to pony $B$, and similarly from $B$ to $A$; this was done on three consecutive days. Finally, species from $A$, which had not become established in the ventral colon of pony $B$ by either of these methods, were introduced directly through the fistula. During the whole of this part of the experiment both ponies were kept on a hay diet.

\section{RESULTS}

Effect of diet on the concentration of ciliates

The effect of diet on the number of ciliates is shown in Table 1. The diets were fed in the order shown but, owing to the wide daily variation of the counts, it was not possible to distinguish a gradual increase or decrease in the numbers with the passage of time. This variability of the counts could not be accounted for wholly by errors in the method of counting or in sampling the fluid from the colon. The volume of sediment in the sample varied from day to day but bore no relation to the concentration of ciliates in the sample.

The difference between the means of successive pairs of results was therefore tested for significance. Thus in the caecum of pony $A$ there was no detectable effect until oats were added to hay when the mean count fell $(P<0.001)$. In the ventral colon where the ciliates were more concentrated the count rose significantly after the addition of oats to grass $(P<0.001)$, and it again rose 
when the diet consisted of hay only $(P<0.01)$. In pony $B$, the change from grass to hay caused a doubtful fall $(P<0.05)$ in the concentration of ciliates in the ventral colon and had no effect in the caecum or dorsal colon.

Table 1. The effect of diet on the concentration of ciliates

\begin{tabular}{|c|c|c|c|c|c|c|}
\hline Pony & Diet & $\begin{array}{l}\text { Ciliates } \\
\text { /ml.; } \\
\text { mean* } \\
\times 10^{-3}\end{array}$ & $\begin{array}{l}\text { Ciliates } \\
\text { /ml.; } \\
\text { range } \\
\times 1^{-8}\end{array}$ & $\begin{array}{l}\text { Standard } \\
\text { error of } \\
\text { the mean }\end{array}$ & $\begin{array}{c}\text { Difference } \\
\text { between } \\
\text { means } \\
\times 10^{3}\end{array}$ & $\begin{array}{l}\text { Value } \\
\text { of } P\end{array}$ \\
\hline \multicolumn{7}{|c|}{ Caecum } \\
\hline $\begin{array}{l}\boldsymbol{A} \\
\boldsymbol{A} \\
\boldsymbol{A} \\
\boldsymbol{A}\end{array}$ & $\begin{array}{l}\text { Grass } \\
\text { Grass + oats } \\
\text { Hay } \\
\text { Hay + oats }\end{array}$ & $\begin{array}{r}20 \cdot 6 \\
17 \cdot 3 \\
17 \cdot 8 \\
7 \cdot 7\end{array}$ & $\begin{array}{l}9-47 \\
4-36 \\
7-33 \\
1-33\end{array}$ & $\left.\begin{array}{l}2 \cdot 302 \\
1 \cdot 986 \\
1 \cdot 549 \\
1 \cdot 717\end{array}\right\}$ & $\begin{array}{r}-\mathbf{3 \cdot 3} \\
\mathbf{0 \cdot 0} \\
-\mathbf{9} \cdot \mathbf{6}\end{array}$ & $\begin{array}{c}<0.2 \\
<0.001\end{array}$ \\
\hline$\underset{B}{\boldsymbol{B}}$ & $\begin{array}{l}\text { Grass } \\
\text { Hay }\end{array}$ & $\begin{array}{l}18 \cdot 4 \\
10 \cdot 3\end{array}$ & $\begin{array}{l}3-53 \\
6-19\end{array}$ & $\left.\begin{array}{l}2 \cdot 501 \\
0 \cdot 706\end{array}\right\}$ & $-\mathbf{3} \cdot \mathbf{1}$ & $<0.9$ \\
\hline \multicolumn{7}{|c|}{ Ventral colon } \\
\hline $\begin{array}{l}\boldsymbol{A} \\
\boldsymbol{A} \\
\boldsymbol{A} \\
\boldsymbol{A}\end{array}$ & $\begin{array}{l}\text { Grass } \\
\text { Grass + oats } \\
\text { Hay } \\
\text { Hay + oats }\end{array}$ & $\begin{array}{l}111 \\
294 \\
870 \\
695\end{array}$ & $\begin{array}{c}22-162 \\
14-472 \\
85-3072 \\
132-1928\end{array}$ & $\left.\begin{array}{r}8 \cdot 672 \\
21 \cdot 096 \\
215 \cdot 385 \\
121 \cdot 944\end{array}\right\}$ & $\begin{array}{l}+183 \\
+576 \\
-175\end{array}$ & $\begin{array}{l}<0.001 \\
<0.01 \\
<0.5\end{array}$ \\
\hline $\begin{array}{l}\boldsymbol{B} \\
\boldsymbol{B}\end{array}$ & $\begin{array}{l}\text { Grass } \\
\text { Hay }\end{array}$ & $\begin{array}{l}62 \cdot 8 \\
31 \cdot 4\end{array}$ & $\begin{array}{l}2-253 \\
7-89\end{array}$ & $\begin{array}{r}16 \cdot 363 \\
1 \cdot 162\end{array}$ & $-31 \cdot 4$ & $<0.05$ \\
\hline \multicolumn{7}{|c|}{ Dorsal colon } \\
\hline $\boldsymbol{B}$ & Hay & $\begin{array}{l}043 \\
495\end{array}$ & $\begin{array}{c}67-105 b \\
129-929\end{array}$ & $\left.\begin{array}{l}65.410 \\
51 \cdot 943\end{array}\right\}$ & -150 & $<0 \cdot 1$ \\
\hline
\end{tabular}

The density of the ciliate population in each part of the gut is evident: the numbers are low and relatively constant in the caecum, high and variable in the ventral colon, high but less variable in the dorsal colon. The smaller number of ciliates in the ventral colon of pony $B$ was associated with differences in the type of fauna (see later).

\section{Effect of diet on the distribution of species}

Tables 2-4 show the effect of diet on the distribution of species. The wide variability in the range of the proportions of each species is a feature common to all three tables.

Caecum. Change of diet had no pronounced effect on the composition of the fauna. Cycloposthium bipalmatum, Blepharocorys jubata and B. uncinata are the three species typical of the caecum. In pony $A$, where only $C$. bipalmatum and $B$. jubata were present, hay appeared to favour $C$. bipalmatum and to depress $B$. jubata. In pony $B$, where the two species of Blepharocorys occurred together, $B$. uncinata was the more abundant; it showed an increase on hay while $C$. bipalmatum decreased.

Ventral colon. Twelve species occurred in the ventral colon of pony $\boldsymbol{A}$ but only those which formed more than $10 \%$ of the population will be considered. The species are all characteristic of the proximal fauna but their proportions in the caecum and ventral colon differ. When the grass diets are compared with the hay diets, it is seen that on hay or hay and oats Blepharoprosthium ampulla became the dominant species and formed 63 and $68 \%$ of the 
Table 2. Species distribution in the caecum

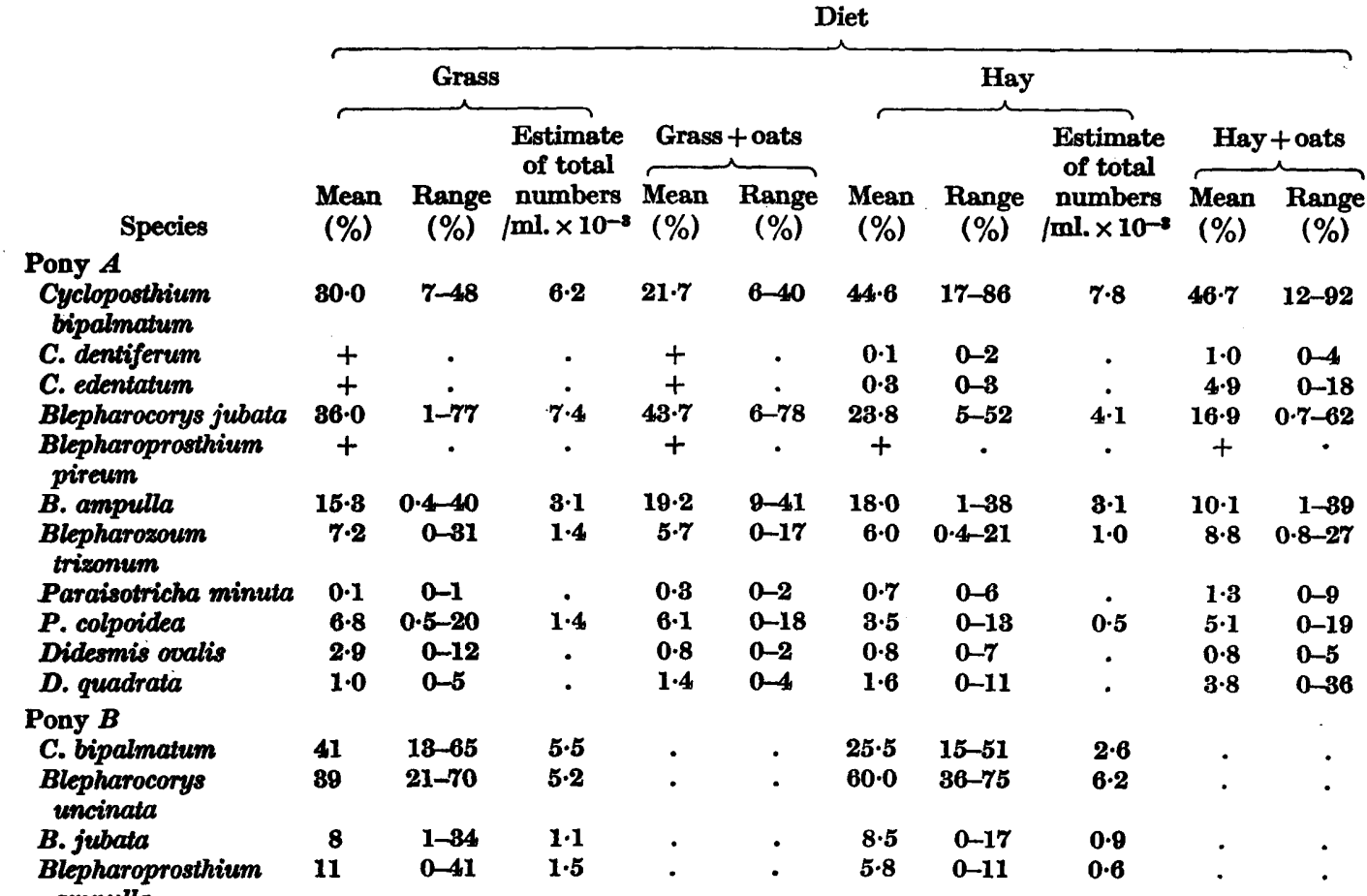

Table 3. Species distribution in the ventral colon

Diet

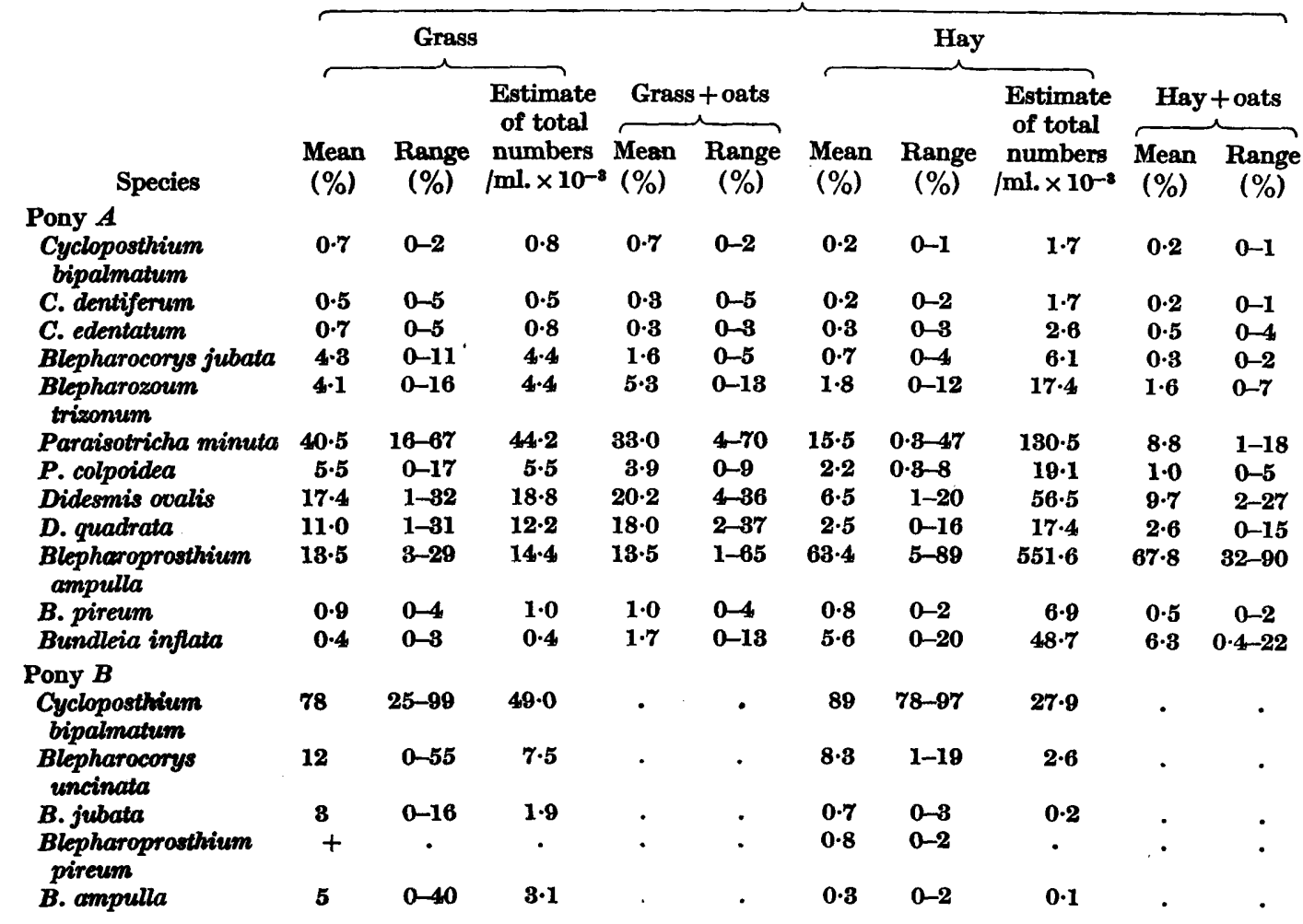


population. On the grass diets, however, Paraisotricha minuta was the most numerous with Didesmis ovalis and $D$. quadrata forming an appreciable part of the fauna. A further point to be noted is that the actual concentration of $P$. minuta increased from $44,200 / \mathrm{ml}$. on grass to $130,500 / \mathrm{ml}$. on hay, although the proportion actually fell from 40 to $15 \%$. The proportion and number of $B$ undleia inflata rose conspicuously on hay or hay plus oats. In pony $B$ the composition of the fauna was much more restricted, only five species being present; of these C. bipalmatum was the most abundant.

Table 4. Species distribution in the dorsal colon

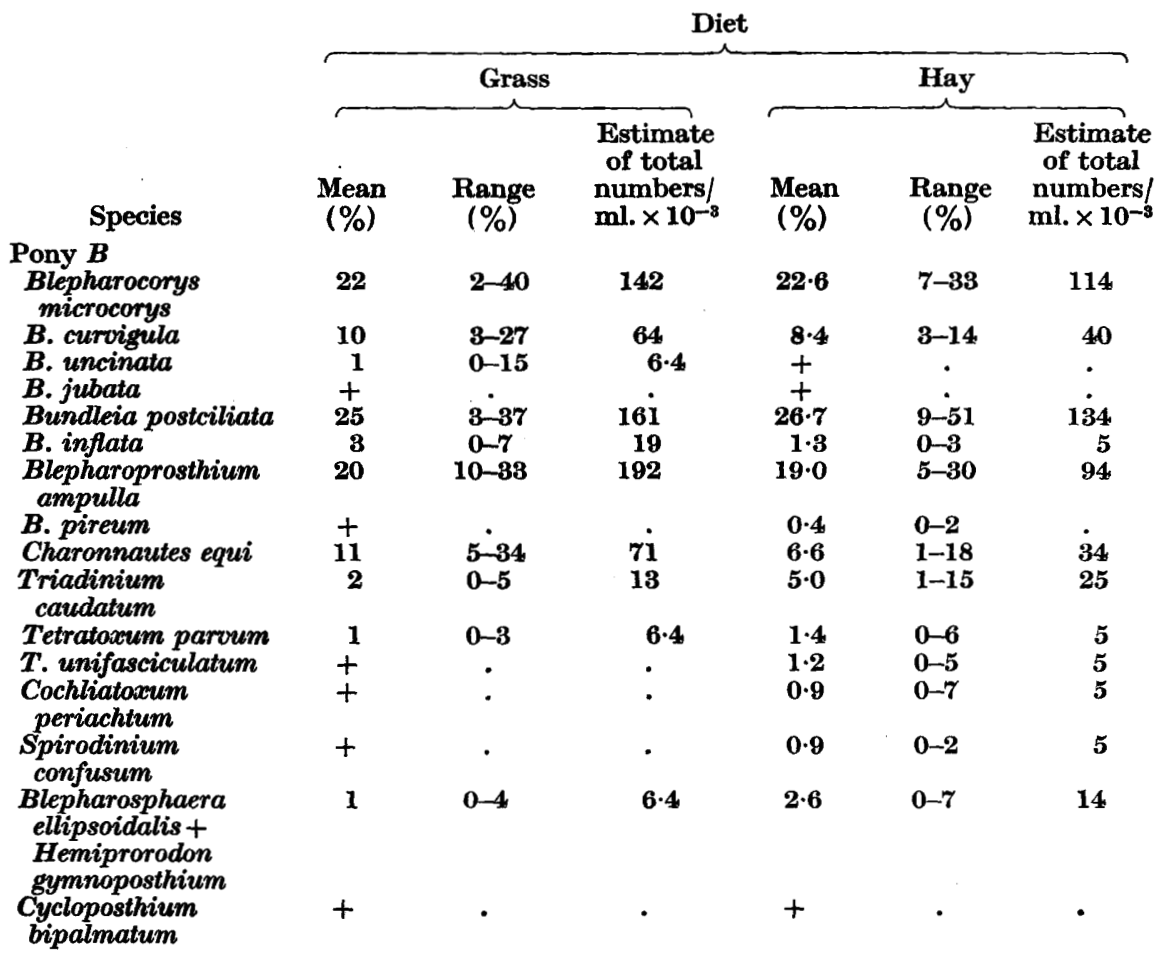

Dorsal colon. The variety of species observed is typical of the distal fauna. Blepharocorys spp. and Bundleia spp. are commonly numerous in this part of the gut. The proportions of each species remained remarkably constant on the two diets. Nevertheless, on the hay diet there was a slight increase in the number of oligotrichs, namely, Triadinium caudatum, Tetratoxum parvum, T. unifasciculatum, Cochliatoxum periachtum and Spirodinium confusum.

\section{Transmission of ciliates}

Oral administration of ciliates from pony $A$ to pony $B$. Since pony $B$ would not eat fresh colon contents mixed with oats, the digesta had to be introduced by stomach tube. This was done on two occasions. After the first dose, Cycloposthium edentatum became established in the ventral colon, and after the second dose $C$. dentiferum became part of the same fauna. C. edentatum 
was not identified until the 8th day after the dose, when a single specimen was seen. On the 10th day several specimens were seen but the species still formed less than $1 \%$ of the population; on the 11 th day it formed $7 \%$; on the 12 th day, $11 \%$; on the 13th day, $14 \%$, and on the 14th day, $26 \%$, and then increased no further.

As the concentration of $C$. edentatum increased so the digesta became noticeably greyish in colour, and when allowed to stand for a few minutes a conspicuous white layer formed at the bottom of the beaker. This white layer was due to the rapid sedimentation of the relatively heavy $C$. edentatum. On one occasion the concentration of this ciliate was so dense $(143,000 / \mathrm{ml}$.) that the gut contents were very pale in colour and, on settling, a layer of C. edentatum separated out which formed about $25 \%$ of the volume of the sample.

The spread of $C$. dentiferum was slower and not followed in the same detail. It appeared only in small numbers 2 weeks after it had been introduced: by the end of 6 weeks it was as numerous as $C$. edentatum, and these two large species of Cycloposthium remained in about equal numbers.

No new species were transmitted by feeding oats contaminated with fresh faeces. The faeces contained species which were identified mainly as members of the distal fauna; they were non-motile but their structure appeared to be unaltered; no cysts were seen.

Administration through the fistula. When the contents of the ventral colon of pony $A$ were introduced directly into the ventral colon of $B$ through the fistula, the new species became established rapidly. On the 3rd day after the infection, all five new species were detected in the new host; after 5 days all were well established and formed a considerable proportion of the fauna, e.g. P. minuta $1 \%, D$. ovalis $27 \%, D$. quadrata $25 \%$, Paraisotricha colpoidea $4 \%$, and Blepharozoum trizonum $9 \%$.

In pony $B$ the ventral colon contents were always rather pale, strawcoloured, but when the fauna of the two ponies became the same, the gut contents of $B$ became deep, olive-brown in colour, which was the typical appearance of the ventral colon contents of $A$.

The fauna of the caecum of pony $B$ was not affected by the changes in the fauna of its ventral colon, but the numbers of ciliates in the dorsal colon decreased significantly $(P<0.001)$. The results of these experiments are presented in Table 5.

Density of the population. After the introduction of $C$. edentatum into the ventral colon of pony $B$, there was approximately a sixfold increase in the total number of ciliates and this difference was significant $(P<0 \cdot 001)$. After the introduction of all species the total number showed a further fourfold increase, which was again significant $(P<0.001)$. This brought the total number of the ciliate population in $B$ very close to that of $A$.

Distribution of species. When $C$. edentatum alone was introduced into pony $B$ it became the second most abundant species, supplanting $C$. bipalmatum despite the rise in concentration of this ciliate from $28,000 / \mathrm{ml}$. to $37,000 / \mathrm{ml}$. B. ampulla, which had previously formed only $0.3 \%$ of the population increased 
to $47 \%$. B. inflata and Blepharosphaera intestinalis appeared for the first time in the fauna of the ventral colon; they had previously been confined to that of the dorsal colon. All species from pony $A$ became successfully established in pony $B$, but the distribution of species in the two ponies remained different. $\boldsymbol{B}$. trizonum became the dominant species in pony $\boldsymbol{B}$ and, although the proportion of $C$. edentatum fell from 31 to $9 \%$, its actual number increased slightly.

Table 5. Effect of introducing nero species into the ventral colon

\begin{tabular}{|c|c|c|c|c|c|c|c|c|}
\hline \multirow[b]{3}{*}{ Species } & \multicolumn{4}{|c|}{ Normal fauns } & \multirow{2}{*}{\multicolumn{2}{|c|}{$\begin{array}{c}\text { Effect of } C \text {. edentatum } \\
\text { introduced into } \\
\text { pony } B\end{array}$}} & \multirow{2}{*}{\multicolumn{2}{|c|}{$\begin{array}{l}\text { Effect of introducing } \\
\text { all species from } \\
\text { pony } A \text { into pony } B\end{array}$}} \\
\hline & \multicolumn{2}{|c|}{ Pony $A$} & \multicolumn{2}{|c|}{ Pony $B$} & & & & \\
\hline & $\begin{array}{c}\text { Mean } \\
(\%)\end{array}$ & $\begin{array}{l}\text { Estimate } \\
\text { of total } \\
\text { numbers/ } \\
\text { ml. } \times 10^{-\mathrm{s}}\end{array}$ & $\begin{array}{l}\text { Mean } \\
(\%)\end{array}$ & $\begin{array}{l}\text { Estimate } \\
\text { of total } \\
\text { numbers } / \\
\text { ml. } \times 10^{-8}\end{array}$ & $\begin{array}{r}\text { Mean } \\
(\%)\end{array}$ & $\begin{array}{l}\text { Estimate } \\
\text { of total } \\
\text { numbers } / \\
\text { ml. } \times 10^{-8}\end{array}$ & $\begin{array}{l}\text { Mean } \\
(\%)\end{array}$ & $\begin{array}{l}\text { Estimate } \\
\text { of total } \\
\text { numbers } / \\
\text { ml. } \times 10^{-3}\end{array}$ \\
\hline $\begin{array}{l}\text { Cycloposthium } \\
\text { bipalmatum }\end{array}$ & $0 \cdot 2$ & 2 & 89 & $\mathbf{2 8} \cdot 0$ & 20 & 37 & 2 & $14 \cdot 8$ \\
\hline C. edentatum & 0.3 & 2 & - & . & 30.7 & $56 \cdot 2$ & 9 & $66 \cdot 8$ \\
\hline C. dentiferum & 0.2 & $\mathbf{2}$ & - & - & • & $\cdot$ & 8 & $59 \cdot 4$ \\
\hline $\begin{array}{l}\text { Blepharoprosthium } \\
\text { ampulla }\end{array}$ & $68 \cdot 4$ & 551 & 0.3 & 0.1 & 42 & $76 \cdot 8$ & 14 & 104.0 \\
\hline B. pireum & 0.8 & 7 & $0 \cdot 8$ & $0 \cdot 2$ & 1.9 & $\mathbf{3 \cdot 5}$ & 0.7 & $5 \cdot 2$ \\
\hline $\begin{array}{l}\text { Blepharocorys } \\
\text { uncinata }\end{array}$ & $\cdot$ & $\cdot$ & $\mathbf{8 \cdot 3}$ & $\mathbf{2 \cdot 6}$ & $1 \cdot 8$ & $\mathbf{3 \cdot 3}$ & + & $\cdot$ \\
\hline B. jubata & 0.7 & 6 & 0.7 & $0 \cdot 2$ & $0 \cdot 1$ & 0.2 & + & - \\
\hline Bundleia inflata & $5 \cdot 6$ & 49 & · & · & $\mathbf{2 \cdot 0}$ & $\mathbf{3 \cdot 6}$ & + & - \\
\hline $\begin{array}{l}\text { Blepharosphaera } \\
\text { ellipsoidalis }\end{array}$ & + & $\cdot$ & - & - & + & $\cdot$ & 0.3 & $\cdot$ \\
\hline Paraisotricha minuta & $15 \cdot 5$ & 130 & . & . & . & . & $8 \cdot 0$ & $59 \cdot 4$ \\
\hline$P$. colpoidea & $\mathbf{2 \cdot 2}$ & 19 & - & . & - & - & $1 \cdot 0$ & $7 \cdot 4$ \\
\hline Didesmis ovalis & $6 \cdot 5$ & 56 & . & . & . & . & $16 \cdot 0$ & $118 \cdot 8$ \\
\hline D. quadrata & $\mathbf{2 \cdot 5}$ & 17 & - & . & - & - & $12 \cdot 0$ & $89 \cdot 1$ \\
\hline \multirow{2}{*}{$\begin{array}{l}\text { Blepharozoum } \\
\text { trizonum }\end{array}$} & $1 \cdot 8$ & 16 & . & - & - & - & $27 \cdot 0$ & $200 \cdot 6$ \\
\hline & \multicolumn{2}{|c|}{$\begin{array}{c}\text { ciliates } / \mathrm{ml} \text {. } \\
\text { mean } \times 10^{3} 870 \\
\text { s.E. } 215 \cdot 38\end{array}$} & \multicolumn{2}{|c|}{$\begin{array}{c}\text { ciliates } / \mathrm{ml} \text {. } \\
\text { mean } \times 10^{\mathrm{s}} \mathrm{31.4} ; \\
\text { s.E. } 1.16\end{array}$} & \multicolumn{2}{|c|}{$\begin{array}{l}\text { ciliates } / \mathrm{ml} \\
\text { mean } \times 10^{8} 183 \\
\text { s.E. } 29.98\end{array}$} & \multicolumn{2}{|c|}{$\begin{array}{l}\text { ciliates } / \mathrm{ml} \\
\text { mean } \times 10^{3} 743 \\
\text { s.E. } 67 \cdot 72\end{array}$} \\
\hline
\end{tabular}

pH values of the gut contents of pony $B$ are given below. Each is the mean of five determinations:

\begin{tabular}{|c|c|c|c|c|c|c|}
\hline \multirow[b]{2}{*}{ Diet } & \multicolumn{2}{|c|}{ Caecum } & \multicolumn{2}{|c|}{ Ventral colon } & \multicolumn{2}{|c|}{ Dorsal colon } \\
\hline & Mean & Range & Mean & Range & Mean & range \\
\hline $\begin{array}{l}\text { Grass } \\
\text { Hay }\end{array}$ & $\begin{array}{l}6 \cdot 84 \\
6 \cdot 95\end{array}$ & $\begin{array}{l}(6 \cdot 67-6 \cdot 93) \\
(6 \cdot 70-7 \cdot 10)\end{array}$ & $\begin{array}{l}6 \cdot 45 \\
6 \cdot 51\end{array}$ & $\begin{array}{l}(6.29-6.56) \\
(6.43-6.55)\end{array}$ & $\begin{array}{l}6 \cdot 35 \\
6 \cdot 29\end{array}$ & $\begin{array}{l}(6 \cdot 23-6 \cdot 48) \\
(6 \cdot 16-6 \cdot 38)\end{array}$ \\
\hline
\end{tabular}

\section{Conjugation}

In the course of this work thousands of ciliates have been examined but only rarely has conjugation been observed; it was restricted to members of the genus Blepharocorys and the allied species Charonnautes equi. After the introduction of colon contents from pony $A$ into pony $B$ by stomach tube, a few pairs of $C$. bipalmatum were seen in conjugation, and it was once observed in C. edentatum. 


\section{DISCUSSION}

Diet influences the size and composition of the population of micro-organisms in the rumen (Elsden \& Phillipson, 1948). The present attempt to study the effect of diet on the ciliate population in the large intestine of the horse has yielded inconclusive results. In pony $A$ the concentration of ciliates in the ventral colon increased significantly when hay was fed instead of grass, and this was accompanied by definite changes in the proportions of species. In pony $B$, however, the concentration of ciliates in the ventral colon fell when hay replaced grass and the proportions of species were unchanged. The effect of adding oats to grass or hay was also variable. The results suggest that the ciliate population is likely to vary more in the ventral colon than in any other part. By contrast, the caecum appears to be a relatively unfavourable site for ciliate growth, the number there being constantly low and the species few. Again, it would seem that the population of the ventral colon exercises an effect on that of the dorsal colon: in pony $B$ the number of ciliates in the dorsal colon decreased after the fauna of its ventral colon had been changed in size and composition.

The response of the ciliate population to changes in its environment is partly determined by its composition. The results of the experiments on the transmission of ciliates showed how the introduction of a new species affected the existing community. On introducing one new species, C. edentatum, into the ventral colon of pony $B$, the total number of ciliates increased sixfold; the proportion of $B$. ampulla rose significantly; $B$. inflata and $B$. ellipsoidalis extended their range from the dorsal into the ventral colon. After the introduction of six more species there was a further increase in the total number of ciliates accompanied by changes in the proportions of the species.

The division rate of the ciliates can be high; for example, 5 days after $D$. ovalis was introduced into the gut the concentration had increased from about $1 / \mathrm{ml}$. to $249,000 / \mathrm{ml}$. The large and more complex $C$. edentatum also showed a high rate of multiplication when it was colonizing the gut. Thus it seems possible for replacement to keep pace with continual loss due to the posterior movement of the food mass.

When a sample of colon contents was introduced into the host by stomach tube, two species of oligotrichs became established in the ventral colon. Holotrichs were also present in the sample but failed to appear in the colon. It is possible that the holotrichs can only be transferred in the form of cysts. Yet active ciliates from the proximal fauna, including holotrichs, are always present in small numbers in the dorsal colon and have been detected, unchanged, in the faeces. Since the faeces contains predominantly species from the distal fauna, the host is more likely to acquire these than members of the proximal fauna. Evidence in support of this view may be found in the observation of Strelkow (1939) that young horses had fewer species of ciliates than older ones and that the distal fauna contained more species than the proximal. 
I am much indebted to Dr F. Alexander, who operated on ponies for me and thus made it possible for me to carry out these investigations. I am also grateful to Prof. A. Robertson for facilities given me in his Department, and to the Racecourse Totalisator Charity Trust for a grant to purchase and maintain ponies. Mr J. G. Hood has given me much help in the laboratory.

\section{REFERENCES}

ADAM, K. M. G. (1951). The quantity and distribution of the ciliate protozoa in the large intestine of the horse. Parasitology, 41, 801.

Alexander, F. (1952). Some functions of the large intestine of the horse. Quart. J. exp. Physiol. 37, 205.

Ersden, S. R. \& Prilurpson, A. T. (1948). Ruminant digestion. Annu. Rev. Biochem. 17, 705.

Strelkow, A. (1939). Parasitic Infusoria from the intestine of Ungulata of the family Equidae. Uchen. Zap. pedagog. inst. im. Gercena. 17, 262.

(Received 2 May 1953) 